\title{
Effect of Mangkokan (Polyscias scutellaria) Leaf Extract on Blood Sugar Levels in Alloxan-Induced Male White Rats
}

\author{
Sri Lestari Ramadhani Nasution, ${ }^{1}$ Awanis, ${ }^{2}$ Stiven Elsafarindo ${ }^{2}$ \\ ${ }^{1}$ Department of Public Health,Faculty of Medicine Universitas Prima Indonesia, Medan, Indonesia, \\ ${ }^{2}$ Faculty Medicine Universitas Prima Indonesia, Medan, Indonesia
}

\begin{abstract}
Type 2 diabetes is a metabolic disorder caused by insulin resistance and is associated with oxidative stress. In Indonesia, the mean prevalence of diabetes ranges from 1.4\% to 1.6\%; however, some areas have a much higher diabetes prevalence such as Pekajangan (2.3\%) and in Manado (6\%). The 2013 Indonesian Basic Health Research (IBHR) stated that the number of people with DM in Indonesia has reached an alarming rate. This study aimed to determine the antidiabetic effect of Polyscias scutellaria on alloxan-induced male Wistar. This was an experimental study conducted in July 2020 in the Faculty of Medicine, Prima Indonesia University. This study used 25 rats that were grouped into 5 treatment groups: control group (Na-CMC), standard (Metformin), and 3 extract groups with different doses (125 mg/kg BW, $250 \mathrm{mg} / \mathrm{kgBW}$, and $500 \mathrm{mg} / \mathrm{kgBW})$. Mangkokan leaf extract was obtained through the maceration method. All rats were induced intraperitoneally using alloxan monohydrate $10 \%$ at a dose of $175 \mathrm{mg} / \mathrm{kgBW}$. The parameters used in this study were fasting blood glucose level before induction, after induction, and after treatment and body weight before treatment. It was observed that there was a significant change in blood glucose level between the extract groups. The blood sugar level in the $125 \mathrm{mg} / \mathrm{kgBW}$ group was $495.00 \mathrm{mg} / \mathrm{dL}$ while in the $250 \mathrm{mg} / \mathrm{kg} \mathrm{BW}$ and $500 \mathrm{mg} / \mathrm{kgBW}$, the blood glucose levels were $317.00 \mathrm{mg} / \mathrm{dL}$ and $126.00 \mathrm{mg} / \mathrm{dL}$, respectively, with the $500 \mathrm{mg} / \mathrm{kgBW}$ dose as the most effective dose (P-value=0.001). Thus, mangkokan leaves have the potential to reduce blood glucose level but are not as good as the standard group.
\end{abstract}

Keywords: Blood glucose level, mangkokan leaves, metformin, pancreas

\section{Pengaruh Ekstrak Daun Mangkokan (Polyscias scutellaria) terhadap Kadar Gula Darah Tikus Putih Jantan yang Diinduksi Aloxan}

\begin{abstract}
Abstrak
Diabetes Mellitus Tipe 2 merupakan gangguan metabolisme disebabkan oleh resistensi insulin dan berkaitan dengan stress oksidatif. Di Indonesia, rata-rata diabetes berkisar antara 1,4-1,6\%, namun, beberapa daerah memiliki prevalensi diabetes yang jauh lebih tinggi seperti Pekajangan (2,3\%) dan di Manado (6\%). Berdasar atas laporan Riskesdas 2013, menyebutkan bahwa jumlah penderita DM di Indonesia sudah mencapai angka yang mengkhawatirkan. Penelitian ini bertujuan mengetahui efek antidiabetik dari daun mangkokan pada tikus wistar jantan yang diinduksi dengan aloksan. Penelitian ini merupakan penelitian eksperimental yang dilakukan pada bulan Juli 2020 di Fakultas Kedokteran Universitas Prima Indonesia. Penelitian ini menggunakan 25 ekor tikus yang dikelompokkan dalam 5 kelompok perlakuan, yaitu kelompok kontrol (Na-CMC), standar (Metformin), dan 3 kelompok ekstrak dengan dosis berbeda (125 mg/kgBB, $250 \mathrm{mg} / \mathrm{kgBB}$, dan $500 \mathrm{mg} / \mathrm{kgBB}$ ). Ekstrak daun mangkokan diperoleh melalui metode maserasi. Seluruh tikus yang digunakan diinduksi terlebih dahulu dengan menggunakan aloksan monohydrate $10 \%$ dengan dosis $175 \mathrm{mg} / \mathrm{kgBB}$ ) secara intraperitoneal. Parameter penelitian yang digunakan dalam penelitian ini adalah kadar gula darah (KGD) puasa sebelum induksi, sesudah induksi, dan setelah perlakuan, serta berat badan sebelum perlakuan. Diamati bahwa ada perubahan yang signifikan dalam kadar glukosa darah antara kelompok ekstrak. Kadar gula darah pada kelompok $125 \mathrm{mg} /$ $\mathrm{kgBB}$ adalah 495,00 mg/dL sedangkan pada kelompok $250 \mathrm{mg} / \mathrm{kgBB}$ dan $500 \mathrm{mg} / \mathrm{kgBB}$ berturut-turut adalah $317.00 \mathrm{mg} / \mathrm{dL}$ dan $126.00 \mathrm{mg} / \mathrm{dL}$ dengan $500 \mathrm{mg} / \mathrm{kgBB}$ sebagai dosis paling efektif $(\mathrm{p}=0,001)$. Simpulan, daun mangkokan berpotensi menurunkan KGD namun tidak sebagus kelompok standar.
\end{abstract}

Kata kunci: Daun mangkokan, etanol, kadar gula darah, metformin, pankreas

Corresponding Author: Sri Lestari Ramadhani Nasution, Department of Public Health,Faculty of Medicine Universitas Prima Medan, Jalan Belanga No 1 Simpang Ayahanda Medan, Indonesia, Email: srilestariramadhaninasution@unprimdn.ac.id 


\section{Introduction}

Diabetes mellitus (DM) is a group of metabolic diseases characterized by hyperglycemia due to abnormalities in insulin secretion, insulin action, or both. The World Health Organization (WHO) has previously stated that DM is a disease that cannot be expressed in one clear and concise answer, but in general, it can be said to be a collection of anatomic and chemical problems resulting from a number of factors including absolute or relative insulin deficiency and insulin function disorders. ${ }^{1}$

Type 1 diabetes is characterized by absolute insulin deficiency caused by lesions or necrosis of beta cells of Langerhans and the loss of beta cell function that may be due to viral invasion. In addition, this deficiency may also be caused by the action of chemical toxins or the action of autoimmune antibodies against beta cells. As a result of the destruction of pancreatic beta cells, they fail to respond to glucose inputs. ${ }^{2}$

Based on the 2013 estimation results from the International Diabetes Federation (IDF), it is stated that the increase in prevalence of this disease is in line with the global trends, where in 2000, the IDF estimated the prevalence of diabetes of $3.2 \%$, which continued to increase to $6.5 \%$ in 2013 . This increase will continue and is predicted to reach $10.1 \%$ by $2035 .^{3}$

Meanwhile, in developing countries, a quite significant increase in prevalence is predicted, especially in countries that adopt a westernized culture. There are 10 countries with the highest prevalence of type 2 DM: Tokelau (37.5\%), Federated States of Micronesia (35\%), Marshall Islands (34.9\%), Kiribati (28.8\%), Cook Islands (25.7\%), Vanuatu (24\%), Saudi Arabia (24\%), Nauru (23.3\%), Kuwait (23.1\%), and Qatar $(22.9 \%) .^{3}$ Indonesia has a diabetes prevalence that ranges from $1.4 \%$ to $1.6 \%$, except in some places, such as Pekajangan (2.3\%) and Manado (6\%). Based on the 2013 Basic Health Research data, the number of people with DM in Indonesia is very large with the possibility of an increase in the number of people with DM in the future. Thus, this disease will create a very heavy burden for the specialists/subspecialists or even for all health workers in the country. ${ }^{4}$ This is apparent from the increase in the prevalence of diabetes mellitus based on doctor's diagnosis from 1.3 in 2013 to $2.0 \%$ in 2018 . The five provinces with the largest prevalence of diabetes mellitus in Indonesia are DKI Jakarta, East Kalimantan, DI Yogyakarta, North Sulawesi, and East Java. Diabetes in Indonesia is more prevalent in women $(1.8 \%)$ than men $(1.2 \%)$, with the peak prevalence of diabetes mellitus at the age of 5564 years with $6.3 \% .^{2,5,6}$

The increasing prevalence of the childhood obesity seems to affect the onset of type 2 diabetes, especially among children and young adults in risk ethnic groups. ${ }^{7}$ There are still many other risk factors that affect the prevalence of diabetes, such as physical activity, exposure to smoke, blood pressure, etc. ${ }^{8}$

One of the factors suggested to lead to pose a risk of hyperglicemic state is inflamation. In general, inflammation is supposed to restore inflamed tissue; however, recent research has shown that chronic inflammation can lead to the release of several chemicals known as Reactive Oxygen Species (ROS) which further classify the pre-inflammatory cascade, leading to a possible risk of developing a hyperglicemic state. ${ }^{9}$

Patients with type 1 diabetes mellitus often require exogenous insulin to treat hyperglycemia. When not treated, these patients may experience ketosis, which often occurs in adolescents and sometimes adults. ${ }^{5}$

Therefore, it is important to find effective drugs at affordable prices using local resources with relatively few side effects, one of which is mangkokan leaf (Polycias scutellaria) that contains various phytochemicals, such as flavonoids and saponins. These compounds have antioxidant activities and can improve oxidative stress in the body. Several previous studies have been conducted to explore other pharmacological effects of this plant, such as its effect on hair growth and its antibacterial effects. $^{10,11}$ However, no previous studies have explored the effects of mangkokan leaves on fasting blood sugar levels. This study aimed to explore the effects of mangkokan leaf extract on fasting blood sugar levels as a diabetes control in alloxan-induced male Wistar rats.

\section{Methods}

This was an experimental post-test only study to assess differences in blood sugar levels in different groups of rats. The protocol was approved and the ethical clearance was issued by the Health Research Ethics Committee of Faculty of Medicine, University of Prima Indonesia (Ethical Clearance No: 041/KEPK/ UNPRI/V/2020).

This research was conducted on White Rats in the White Rat Laboratory (Riwandi Animal House) of Medan City from July-August 2020. The 
animals were divided into 5 treatment groups according to the following formula, resulting in 25 rats divided evenly into the 5 groups:

$$
\begin{aligned}
& (5-1)(N-1) \geq 15 \\
& (4)(N-1) \geq 15 \\
& (N-1) \geq 15 / 4 \\
& N-1 \geq 3,75 \\
& N \geq 4.75 \approx 5
\end{aligned}
$$

The mangkokan leaf samples used in this study were collected from several places around the Medan Petisah sub-district, which were then identified in the Medanese Herbarium of the Faculty of Math and Natural Science of the University of North Sumatra.

The identified mangkokan leaf samples were then cleaned and then aerated for 7 days until they became dry simplicia, and then crushed into dry simplicia powder. The dry simplicia powder was macerated using ethyl acetate as the solvent $(1: 15 \mathrm{~g} / \mathrm{mL})$ for 5 days, the mixture was stirred regularly and constantly every day. After five days, the mixture was filtered using Whatmann filter paper no. 1 , and the residue is re-macerated using the same method but the solvent used is half of the previous maceration volume. The maceration process was carried out three times, then the filtrate of each maceration and re-maceration was evaporated using a rotary evaporator at a temperature of $70^{\circ} \mathrm{C}$, followed by drying using an oven at $40^{\circ} \mathrm{C}$ to become a thick extract. ${ }^{12,13}$

The phytochemical test was performed using a modified Fansworth method of identification of phenols, steroids/triterpenoids, terpenoids, saponins, flavonoids, tannins and alkaloids. ${ }^{14}$

All male wistar rats were housed in standard polypropylene cages in an environment suitable for the animals with maintained light-dark cycles. The White Rats underwent adaptation for one week to a normal pellet diet and fed ad libitum. After one week, male wistar rats were fasted overnight before 10\% Alloxan Monohydrate $10 \%$ was injected intraperitoneally to induce diabetic condition. A total of $0.35 \mathrm{~mL}(175 \mathrm{mg} /$ $\mathrm{kg} \mathrm{bw)} \mathrm{10 \%} \mathrm{Alloxan} \mathrm{monohydrate} \mathrm{was} \mathrm{injected}$ intraperitoneally. To ensure the induction was successful, the fasting blood sugar level was measured after 72 hours and the diabetic state was established when the blood sugar level was more than $200 \mathrm{mg} / \mathrm{L}(11.1 \mathrm{mmol} / \mathrm{L}){ }^{15}$

Anti-diabetic activity testing was carried out on the 25 alloxan-induced rats which were grouped into five treatment groups as described in Table 1:

The blood sugar level measured in this study was the fasting plasma glucose (FPG). The FPG was measured in mice that had been fasted for 10-12 hours before measurement. Blood samples from mice were drawn from the veins of the rats, 72 hours after induction (FPG 0) and on day 28 (FPG 28) after the rats were given mangkokan leaf extract and metformin as standard. ${ }^{16}$

Data analysis was performed using IBM SPSS 25. Data were in the form of phytochemical screening results, FPG 0, and FGP 28. The FPG 0 and FPG 28 data were analyzed for normality using the Shapiro-Wilk test. If the data were normally distributed, the analysis continued with one-way ANOVA and Post Hoc Test. However, if the data were not normally distributed, the analysis performed would be the non-parametric test using the Kruskal-wallis test.

\section{Results}

As the first step of this study, samples of the mangkokan leaves obtained were identified in

\begin{tabular}{|c|c|}
\hline Treatment Group & Treatment \\
\hline Control & $\begin{array}{l}\text { Rats in this group received } 1 \mathrm{ml} \text { of } 0.5 \% \mathrm{Na}-\mathrm{CMC} \text { suspension. Food } \\
\text { and drink was given ad libitum. }\end{array}$ \\
\hline Standard & $\begin{array}{l}\text { Rats in this group received } 1 \mathrm{ml} \text { of metformin oral suspension } 250 \\
\mathrm{mg} / \mathrm{kgBW} \text {. Food and drink was given ad libitum. }\end{array}$ \\
\hline Extract Dosage of $125 \mathrm{mg} / \mathrm{kgBW}$ & $\begin{array}{l}\text { Rats in this group received } 1 \mathrm{ml} \text { of the extract oral suspension at } \\
\text { dose of } 125 \mathrm{mg} / \mathrm{kgBW} \text {. Food and drink was given ad libitum. }\end{array}$ \\
\hline Extract Dosage of $250 \mathrm{mg} / \mathrm{kgBW}$ & $\begin{array}{l}\text { Rats in this group received } 1 \mathrm{ml} \text { of the extract oral suspension at } \\
\text { dose of } 250 \mathrm{mg} / \mathrm{kgBW} \text {. Food and drink was given ad libitum. }\end{array}$ \\
\hline Extract Dosage of $500 \mathrm{mg} / \mathrm{kgBW}$ & $\begin{array}{l}\text { Rats in this group received } 1 \mathrm{ml} \text { of the extract oral suspension at } \\
\text { dose of } 500 \mathrm{mg} / \mathrm{kgBW} \text {. Food and drink was given ad libitum. }\end{array}$ \\
\hline
\end{tabular}
the Herbarium Medanese, University of North Sumatra. The results of the identification of the leaf samples are as follows:

\section{Table 1 Rats Treatment Group}


Table 2 Results of Phytochemical Screening of Mangkokan Leaf Ethanol Extract (Polycias scutellaria)

\begin{tabular}{llc}
\hline \multicolumn{1}{c}{ Phytochemicals } & \multicolumn{1}{c}{ Method } & Interpretation \\
\hline \multirow{2}{*}{ Alkaloids } & Bouchardart & + \\
& Maeyer & - \\
& Wagner & + \\
Triterpenoids and Steroids & Dragendorff & + \\
Saponins & Salkowsky & + \\
& Lieberman-Burchad & + \\
Flavonoids & Aquadest + Alkohol $96 \%$ & + \\
& $\mathrm{FeCl}_{3} 5 \%$ & - \\
Tanins & $\mathrm{Mg}_{(\mathrm{s})}+\mathrm{HCl}(\mathrm{p})$ & - \\
\hline
\end{tabular}

$\begin{array}{ll}\text { Kingdom } & \text { : Plantae } \\ \text { Division } & \text { : Spermatophyta } \\ \text { Class } & \text { : Dicotyledoneae } \\ \text { Order } & \text { : Apiales } \\ \text { Family } & \text { : Araliaceae } \\ \text { Genus } & \text { : Polycias } \\ \text { Species } & \text { : Polycias scutellaria (Burm. F) } \\ & \text { Fosberg } \\ \text { Local Name } & \text { : Mangkokan Leaf }\end{array}$

Prior to the antidiabetic activity testing of the ethanol extract of mangkokan leaves, the ethanol extract of the mangkokan leaves was screened for phytochemicals. The results of phytochemical screening on the mangkokan leaf extract are listed in Table 2, showing that the leaves contains several phytochemicals: alkaloids, triterpenoids and steroids, saponins, flavonoids, and tannins.

Before the hypothesis for each parameter was tested, data normality analysis was carried out using the Shapiro-Wilk test. The results of the data normality analysis is listed in Table 3. In this table, it is obvious that from all parameters evaluated in this study, only body weight was normally distributed ( $\mathrm{p}$-value $>0.05$ ). In contrast, blood sugar levels were not normally distributed ( $p$-value $<0.05$. Thus, the body weight data were analyzed using the One Way Anova test, while the blood sugar data were analyzed using the Kruskall-Wallis test.

In analyzing the antidiabetic activities of ethanol extract of the mangkokan leaves, several

Table 3 Results of Data Normality Analysis for Each Parameter

\begin{tabular}{clc}
\hline \multicolumn{1}{c}{ Parameter } & \multicolumn{1}{c}{ Treatment Group } & P Value \\
\hline & Control & 0.780 \\
Blood Sugar Level Before Induction & Standard & 0.627 \\
& Extract Dosage of $125 \mathrm{mg} / \mathrm{kgBW}$ & 0.532 \\
& Extract Dosage of $250 \mathrm{mg} / \mathrm{kgBW}$ & 0.115 \\
& Extract Dosage of $500 \mathrm{mg} / \mathrm{kgBW}$ & 0.024 \\
Blood Sugar Level After Induction & Control & 0.792 \\
& Standard & 0.266 \\
& Extract Dosage of $125 \mathrm{mg} / \mathrm{kgBW}$ & 0.255 \\
& Extract Dosage of $250 \mathrm{mg} / \mathrm{kgBW}$ & 0.995 \\
& Extract Dosage of $500 \mathrm{mg} / \mathrm{kgBW}$ & 0.015 \\
Blood Sugar Level After Treatment & Control & 0.042 \\
& Standard & 0.029 \\
& Extract Dosage of $125 \mathrm{mg} / \mathrm{kgBW}$ & 0.159 \\
& Extract Dosage of $250 \mathrm{mg} / \mathrm{kgBW}$ & 0.837 \\
\hline
\end{tabular}


Table 4 Comparison of Blood Sugar Level in Each Treatment Group

\begin{tabular}{lccc}
\hline \multicolumn{1}{c}{ Treatment } & Before Induction & After Induction & After Treatment \\
\hline Control & $105.50(24.00)$ & $425.00(14.00)$ & $583.50(35.00)$ \\
Standard & $116.50(48.00)$ & $416.00(33.00)$ & $114.00(16.00)^{\mathrm{a}}$ \\
Extract Dosage of $125 \mathrm{mg} / \mathrm{kgBW}$ & $106.50(40.00)$ & $405.50(27.00)$ & $495.00(59.00)^{\mathrm{ab}}$ \\
Extract Dosage of $250 \mathrm{mg} / \mathrm{kgBW}$ & $103.50(9.00)$ & $402.00(17.00)$ & $317.00(198.00)^{\mathrm{ab}}$ \\
Extract Dosage of $500 \mathrm{mg} / \mathrm{kgBW}$ & $104.50(7.00)$ & $400.50(31.00)$ & $126.00(21.00)^{\mathrm{ab}}$ \\
P value & 0.608 & 0.198 & 0.001 \\
\hline
\end{tabular}

parameters were assessed, including the blood sugar levels before induction, blood sugar levels after induction, and blood sugar levels after treatment.

No significant difference in blood sugar level before and after induction was identified between each treatment group, as described in Table 4 ( $\mathrm{p}$-value $>0.05$ ). This shows that the blood sugar levels before and after induction between each group were quite uniform.

\section{Discussion}

This study demonstrates that the mangkokan leaf extract decreases fasting blood glucose significantly, which may be due to the ethanol extract in the leaf that consists of phytochemical compounds, such as alkaloids, triterpenoids and steroids, saponins, flavonoids, and tannins.

The results of this study support the results of research conducted by Nasution et al. and Revina et al. who reported that the ethanol extract of the leaves contains several phytochemical compounds such as alkaloids, saponins, tannins, and flavonoids. The phytochemical content of this ethanol extract provides various benefits, including its role as antioxidant, antibacterial, and antidiabetic agents. It also supports hair growth and wound healing. ${ }^{10-12,17,18}$

Among the various benefits of the mangkokan leaves, the ethanol extract of mangkokan leaves is shown to have anti-hyperglycemic effects in the present study. The anti-hyperglycemic effect of mangkokan leaves is due to its saponin content. Saponins contained in mangkokan leaves take the form of olenolic acid, which inhibits the action of $\alpha$-glucosidase and $\alpha$-amylase enzymes, thus reducing glucose absorption in the digestive tract and post-prandial blood sugar levels.

In addition to interfering with the glucose absorption in the digestive tract, a previous study by Ighoadaro et al. ${ }^{19}$ also reported ethanol extract of mangkokan leaves as giving antioxidant effects to reduce blood sugar levels in mice that is linked with the mechanism of pancreatic damage caused by alloxan. Alloxan will be reduced by GSH to form dialuric acid, an unstable acid that can bind with antioxidants to form alloxan radicals.

These alloxan radicals will damage pancreatic beta cells through damaging the DNA structure of pancreatic beta cells and inhibiting glucokinase enzyme thiol group. Damage to the DNA structure of pancreatic beta cells will cause death in beta cells, while the observation of the thiol group in the glucokinase enzyme shows interference with the formation of ATP in pancreatic beta cells, causing a decrease in insulin secretion. ${ }^{20}$

The ethanol extract of mangkokan leaves have been proven to contain saponins and flavonoids that are able to produce an antioxidant effect by donating electrons to the alloxan radicals formed, resulting in more stable alloxan compounds and reducing the hazard brought by these alloxans to the pancreatic tissue. ${ }^{12}$ An increasing dose of mangkokan leaf extract is shown in this study to improve the structure of the pancreatic tissue. Overall, it can be concluded that the ethanol extract of mangkokan leaves has an antidiabetic effect on alloxan-induced rats, contributed by saponins and flavonoids, that inhibit the action of the glucosidase enzyme in the gastrointestinal tract and improve the oxidative stress status.

\section{References}

1. Purnamasari D. Diagnosis dan klasifikasi diabetes melitus. In: Setiati S, Alwi I, Sudoyo AW, Simadibrata M, Setiyohadi B, Syam AF, editor. Buku ajar ilmu penyakit dalam. $6^{\text {th }} \mathrm{ed}$. Jakarta: Interna Publishing; 2014. p. 256998.

2. Ndraha S. Diabetes melitus tipe 2 dan tatalaksana terkini. Medicinus. 2014;27(2): 9-16.

3. IDF. Diabetes Atlas Ninth edition 2019. Individual, social and economic impacts. 
Brussels: IDF Advocacy Guide; 2019.

4. Soelistijo SA. Konsensus pengendalian dan pencegahan diabetes melitus tipe 2 di Indonesia. Jakarta: PB PERKENI; 2015.

5. Tarigan THE, Yunir E, Subekti I. Profile and analysis of diabetes chronic complications in outpatient diabetes clinic of Cipto Mangunkusumo Hospital, Jakarta. Med J Indones. 2015;24(3):156-62.

6. Kementerian Kesehatan Republik Indonesia. Hasil utama riset kesehatan dasar. Jakarta: Kementerian Kesehatan RI; 2019; 1-200. https://doi.org/10.1088/17518113/44/8/085201\%.

7. Forouhi NG, Wareham NJ. Epidemiology of diabetes. Medicine (Abingdon). 2014;42(12): 698-702.

8. Isnaini N, Ratnasari R. Faktor risiko mempengaruhi kejadian diabetes mellitus tipe dua. J Kebidanan dan Keperawatan Aisyiyah. 2018;14(1):59-68.

9. Oguntibeju 00. Type 2 diabetes mellitus, oxidative stress and inflammation: examining the links. Int J Physiol Pathophysiol Pharmacol. 2019;11(3):45-63.

10. Amani ZA, Mustarichie R. Review artikel: aktivitas antihiperglikemia beberapa tanaman di Indonesia. Farmaka. 2018;16(1): 127-32.

11. Jubaidah $\mathrm{S}$, Indriani $\mathrm{R}, \mathrm{Sa}$ 'adah $\mathrm{H}$, Wijaya H. Formulasi dan uji pertumbuhan rambut kelinci dari sediaan hair tonic kombinasi ekstrak daun seledri (apium graveolens linn) dan daun mangkokan (polyscias scutellaria (burm.f.) fosberg). J Ilm Manuntung. 2018; 4(1):8-14.

12. Eden WT, Buanasari, Shihabuddin, Badahdah NK. Aktivitas antioksidan ekstrak metanol daun mangkokan (polyscias scutellaria (burn.f.)fosberg). Media Farm Indones.
2016;11(2):1126-35.

13. Rosa D, Halim Y, Kam N, Sugata M, Samantha A. Antibacterial activity of polyscias scutellaria fosberg against acinetobacter $\mathrm{sp}$. Asian J Pharm Clin Res. 2019;12(1):516-9.

14. Widowati W, Wargasetia TL, Afifah E, Mozef T, Kusuma HSW, Nufus H, et al. Antioxidant and antidiabetic potential of Curcuma longa and its compounds. Asian J Agric Biol. 2018; 6(2):149-61.

15. Njagi E N Mwaniki MJM, Njagi J Murugi NMP. In vivo anti-diabetic effects of aqueous leaf extracts of rhoicissus tridentata in alloxan induced diabetic mice. J Dev Drugs. 2015;04(03):1-5.

16. Zubaidah E, Ifadah RA, Kalsum U, Lyrawati D, Putri WDR, Srianta I, et al. Anti-diabetes activity of Kombucha prepared from different snake fruit cultivars. Nutr Food Sci. 2019;49(2):333-43.

17. Revina M, Yuliani R, Putri M, Hulu W, Sinaga A, Nasution SLR. Efektivitas ekstrak daun mangkokan terhadap penyembuhan luka bakar pada tikus. Sci J. 2018;7(2):166-72.

18. Nasution SLR, Revina M, Yuliani R, Nasution SW. The Effectiveness comparison of aloe vera and nothopanax schutellarium exract toward thermal burn on white rat (rattus norvegicus). J Educ Heal Sport. 2019;9(4):580-90.

19. Ighodaro OM, Adeosun AM, Akinloye OA. Alloxan-induced diabetes, a common model for evaluating the glycemic-control potential of therapeutic compounds and plants extracts in experimental studies. Medicina (Kaunas). 2017;53(6):365-74.

20. Vijayaraj R, Kumaran NS, Swarnakala. In vivo and in vitro models for biological screening of anti-diabetic drugs. Int J Pharm Sci. 2019;9(2):294-8. 